\title{
Cell Surface Antigenic Relationship of Pathogenic Mycobacteria
}

\author{
Hyuk Han kwon, M.P.H. and Hajime Saito, M.D., Ph.D. \\ Department of Microbiology and Immunology, Shimane Medical University, Izumo, Japan \\ Sang Jae Kim, Sc.D. \\ Korean Institute of Tuberculosis, Korean National Tuberculosis Association, Seoul, Korea
}

$=$ 국문 초록 $=$

\section{병원성 Mycobacteria의 세포표면항원간의 항원적 상관 관계}

일본 Shimane 의과대학 미생물 및 면역학교실

권혁한, and Hajime Saito

대한결핵협회 결핵연구원

김 상 재

석탄산으로 사멸한 균으로 감작시켜 얻은 토끼 항혈청으로 주요 병원성 mycobacteria의 세포 표면항원간의 항원적 상관관계를 효소결합면역분석법으로 관찰하였다. $M$, avium-intracellulare (MAI) 항혈청을 이용한 동종 및 이종반응 분석결과를 보면 동종내 항원적 상관관계는 매우 가깝고 M. scrofulaceum $(\mathrm{MG})$ 을 포함하면 MAIS군내 종간 항원적 관계도 가까웠다. MAI 혈청 이 $M$. chelonei(MC), fortuitum(MF), nonchromogenicum(MNC), terrae(MTR) 및 triviale (MTV)와는 반응하지 않거나 미약하게 반응하지만 $M$. kansasii(MK)와 결핵균과는 강하게 반응 했다. 그러나 후자의 두균종으로 홉수해도 MAI혈청의 동종반응은 감소되지 않았다. $M$. $\operatorname{avium}(\mathrm{MA})(\mathrm{K} 40004)$ 항혈청은 $M$. intracellulare(MI) 균주를 제외한 다른 균들과는 미약하게 반 응했고 항원적 상관관계가 가까운 $\mathrm{MI}$ 와 $\mathrm{MG}$ 로 흡수하면 동종반응의 50 $89 \%$ 가 감소했다. $\mathrm{MI}$ 혈청의 종내반응이 종간반응보다 물론 더 강하지만 공유항원량의 크기에 따라 달랐다. $\mathrm{MI}$ 균주 중 N-260D, N-260R, N-260T 및 K41014간의 항원적 상관관계가 N-242D, N257T, N281D 및 $\mathrm{N} 275 \mathrm{~T}$ 와의 관계보다 더 가깝게 나타났다.

$\mathrm{MNC}$ 항혈청은 $\mathrm{MC}$ 와 $\mathrm{MTV}$ 를 제외하고는 강한 교차반응을 보여주었다. 종내 항원적 상관관 계 다음으로는 $\mathrm{MTR}$ 와 $\mathrm{MG}(\mathrm{K} 30003)$ 과 가까웠다. $\mathrm{NC}-3$ 혈청은 $\mathrm{MA}, \mathrm{MC}$ 및 $\mathrm{MF}$ 와 상당한 반응 력을 나타내지만 NC-11은 그렇지 않았다. MTR 항혈청은 MI와 강하게 반응하지만 MI로 홉수 한다고 해서 그들의 동종반응이 감소하지 않는 것으로 보아 MTR 표면에 공유항원이 많지 않음 을 보여주었다. MTR과 $\mathrm{MNC}, \mathrm{MC}$ 및 $\mathrm{MF}$ 사이에도 상당량의 공유항원이 있음이 알려졌다. MTR 가운데 T-8 혈청과는 달리 T-13 항혈청은 MA, MG, MK 및 MTB와 강하게 교차반응하 였다.

이상의 실험으로 밝혀진 mycobacteria의 항원적 상관관계가 각종 생물학적 및 생화학적 방법 으로 갈라놓은 분류군과 잘 일치하고 있었다.

Key Words: Pathogenic mycobacteria, Antigenic relationship 


\section{INTRODUCTION}

Most of mycobacterial taxons have been described by the computer-assisted numerical analysis of the various biological and biochemical characteristics that is still considered imperfect to delineate the precise phylogenetic relationships of mycobacteria ${ }^{1,2)}$. Recent development of genomic DNA hybridization technique was found to be very useful to confirm hypothetical phylogeny of the phenetic clusterings based on the various morphological and biochemical characteristics ${ }^{2 \sim 4)}$. In addition, the various immunological procedures also have been studied to delineate the phenetic differences of the species, subspecies, biobars or serobars, some of which had been found useful ${ }^{2,5 \sim 7,9 \sim 10)}$.

A numerous studies on soluble antigenic relationship between mycobacteria have been made by many investigators ${ }^{6,7,10)}$. Relatioship of cell surface antigen also has been studied by seroagglutination technique that was found very useful for serotyping of medically important mycobacteria ${ }^{9}$. However this technique is based on agglutinating antibody directed to the carbohydrate epitopes of the cell surface glycopeptidolipids ${ }^{8}$ and better adapted for smooth colony forming strains ${ }^{8,9}$. All these procedures have advantages and disadvantages depending on the circumstances.

This study aimed to investigate cell surface antigenic relationships between medically important mycobacteria by enzyme immunoassay using antisera raised in rabbits.

\section{MATERIALS AND METHODS}

\section{Mycobacterial Strains}

The following species and strains were used in this study

Mycobacterium tuberculosis $\mathrm{H} 37 \mathrm{Rv}$

M. kansasii $\mathrm{K} 20001$

\section{M. scrofulaceum K30001 \& K30003}

M. avium $\mathrm{K} 40004$

M. intracellulare N-238, N-242D, N-245, N-257R, $\mathrm{N}-257 \mathrm{~T}, \mathrm{~N}-260 \mathrm{~T}, \mathrm{~N}-260 \mathrm{D}, \mathrm{N}$ 260R, N-275R, N-275T, N-279T, N-281D, F 3193 T, K41014

$M$. nonchromogenicum NC-3, NC-6 \& NC-11

M. terrae T-7, T-8 \& T-13

M. triviale V-4 \& V-12

M. chelonei R-20

M. fortuitum F-19

M. smegmatis $\mathrm{K} 64002$

\section{Culture and Immunogen Preparation}

All the strains were cultured on Sauton's broth medium at $37^{\circ} \mathrm{C}$ in a stationary phase by transferring bacterial pellicle formed on the surface of Sauton's potato medium. Few strains that usually does not form pellicle were cultured on a gyrotory shaking incubator at $110 \mathrm{rpm}$. Cells were killed by treating with $2 \%$ phenol for 3 days at $37^{\circ} \mathrm{C}$ and dispersed by a tissue homogenizer and washed 5 times with a sterile $0.067 \mathrm{M}$ phosphate buffered saline ( $\mathrm{pH} 7.0$ ) by centrifugation.

\section{Immunization}

White New-Zealand rabbits weighing $3 \sim 4 \mathrm{~kg}$ were intravenously immunized with phenol killed bacilli according to the following schedule: $1 \mathrm{mg}$ at lst day, $2 \mathrm{mg}$ at $3 \mathrm{rd}$ day, $3 \mathrm{mg}$ at 7 th day, $4 \mathrm{mg}$ at 10 th day and $5 \mathrm{mg}$ at 14 th day. Further immunization with $5 \mathrm{mg}$ of the phenol-killed cells was followed weekly. Rabbits were bled prior to immunization and after 14 days of immunization. If antibody titer of the last serum was same with those of one or two previous sera, animals were subjected to the total bleeding and serum separated was divided into small aliquotes before freezing at $-40^{\circ} \mathrm{C}$. Some strains, for example $\mathrm{K} 40004$ and $\mathrm{N}-260 \mathrm{~T}$, killed animals usually at 14th day intravenous immunization, so that they were immunized subcutaneously every week until 
maximum antibody titer was obtained.

\section{Enzyme Immunoassay}

In order to determine optimum cell concentration for coating, two fold dilutions of $16 \mathrm{mg} / \mathrm{ml}$ cell suspension (to $0.5 \mathrm{mg} / \mathrm{ml}$ ) were reacted with varying serum dilutions and selected optimum dilution of cell suspension that showed a highest reaction. Most of strains showed a highest reaction with $2 \mathrm{mg} / \mathrm{ml}$ of bacterial suspension for coating. Serum dilution that showed a optical density (OD) of 1.0 to 1.3 at $492 \mathrm{~nm}$ was used for assay.

Heterologous cell removable antibodies reacting with homologous organisms (HARD) were measured according to the following formula. Large removal of homologous antibodies with

$$
\begin{gathered}
\text { HARD }(\%)=\frac{\begin{array}{c}
\text { OD of homologous reaction } \\
\text { with unabsorbed serum }
\end{array}}{\begin{array}{c}
\text { OD of homologous reaction } \\
\text { with unabsorbed serum }
\end{array}} \\
\text { - OD of homologous reaction with } \\
\text { heterologous cell absorbed serum } \\
\text { - OD of homologous reaction with } \\
\text { homologous cell absorbed serum }
\end{gathered}
$$

cells from OD heterologous organisms indicates that the homologous cells possess a large amount of cross reacting antigenic epitopes. And homologous cell removable antibodies reacting with heterologous cells (OARH) were also measured according to the following formula in order to estimate relative amoung of cross reactive and specific antigenic determinants.

$$
\begin{gathered}
\text { OARH }(\%)=\frac{\begin{array}{c}
\text { OD of heterologous reaction } \\
\text { with unabsorbed serum }
\end{array}}{\begin{array}{c}
\text { OD of heterologous reaction } \\
\text { with unabsorbed serum }
\end{array}} \\
\text { - OD of heterologous reaction with } \\
\text { homologous cell absorbed serum } \\
\text {-OD of heterologous reaction with } \\
\text { heterologous cell absorbed serum }
\end{gathered}
$$

\section{RESULTS}

Cross reactivity of $M$. terrae antisera (T-8 \& T-13) with other mycobacteria was shown in Table 1 . Both $M$. terrae antisera cross-reacted with a wide range of myobacteria. They showed a strong cross-reaction with strains of $M$. avium, intracellulare, and terrae as their ROD were found to be 1.00 or nearly so $(>0$. 70 ). More than $80 \%$ of these cross-reacting antibody were removed by the homologous absorption, indicating an abundance of shared antigenic determinants on $M$. terrae cell surface. Homologous absorption of T-8 and T-13 antisera removed a largest amount of antibody cross-reacting with strains of $M$. terrae, M. avium (K40004), and certain strains of $M$. intracellulare $\left(\mathrm{N}-260 \mathrm{~T}, \mathrm{~N}-2600, \mathrm{~N}-275 \mathrm{~T}, \mathrm{~F}_{0} 3193 \mathrm{~T}\right.$, K41014), but removed a least amount of antibody reacting with N-257R, N260R, and N-281D. Both strains of $M$. terrae may possess less ammount of antigenic derterminants shared with the latter strains of $M$. intracellulare. Ratios of the heterologous reactions to $M$. tuberculosis, kansasii, scrofulaceum, and fortuitum over the homologous reaction of T-13 antiserum were 1.00 or nearly so, whereas those of T-8 antiserum were less than 0.60 . Cross-reacting antibody to the strains of $M$. chelonei, nonchromogenicum, smegmatis, and triviale were present in a small amount in both sera. It was interest that T-13 antiserum possessed much less amount of antibody to NC-11 than that to NC-3 and both sera also showed a weaker reaction to $\mathrm{V}-12$ than to $\mathrm{V}-4$.

T-8 homologous absorption removed most of cross-reactiong antibody to the strains of $M$. chelonei, nonchromogenicum, scrofulaceum, smegmatis and triviale. Cross-reacting antibody to $M$. fortuitum, kansasii and tuberculosis could be removed relatively less by the homologous absorption, showing $67.9 \%$ to $76.0 \%$ reduction of the corresponding heterologous reaction. Nearly none of T-8 homolgous antibody by the heterologous absorption except 
Table 1. Reactivity of Rabbits Anti-M. terrae Sera (T-8 \& T-13) with Other Mycobacteria

\begin{tabular}{|c|c|c|c|c|c|c|}
\hline \multirow[b]{2}{*}{ Mycobacteria } & \multicolumn{3}{|c|}{$\mathrm{T}-8$} & \multicolumn{3}{|c|}{$\mathrm{T}-13$} \\
\hline & ROD & $\underset{(\%)}{\text { OARH }}$ & $\begin{array}{c}\text { HARD } \\
(\%)\end{array}$ & ROD & $\underset{(\%)}{\text { OARH }}$ & $\begin{array}{c}\text { HARD } \\
(\%)\end{array}$ \\
\hline M. tuberculosis H37Rv & 0.59 & 67.9 & 0.0 & 1.03 & 38.6 & 43.2 \\
\hline M. kansasii $\mathrm{K} 20001$ & 0.54 & 68.6 & 0.0 & 0.89 & 61.8 & 37.0 \\
\hline M. scrofulaceum K30001 & 0.36 & 92.0 & $0.0^{*}$ & 0.77 & $100.0^{*}$ & 27.7 \\
\hline M. scrofulaceum K30003 & 0.55 & 81.7 & 0.0 & 1.20 & 73.5 & 48.8 \\
\hline M. avium K40004 & 1.32 & 85.8 & 0.0 & 1.11 & 100.0 & 35.6 \\
\hline M. intracellulare $\mathrm{N}-238$ & 0.87 & 75.7 & $0.0^{*}$ & 0.92 & 75.0 & 0.0 \\
\hline M. intracellulare N-242D & 0.89 & 76.5 & $0.0^{*}$ & 0.94 & 73.5 & $0.0^{*}$ \\
\hline M. intracellulare N-245 & 0.84 & 80.6 & $0.0^{*}$ & 0.90 & 75.3 & $0.0^{*}$ \\
\hline M. intracellulare $\mathrm{N}-257 \mathrm{~T}$ & 1.28 & 75.8 & $0.0^{*}$ & 1.24 & 69.5 & $0.0^{*}$ \\
\hline M. intracellulare N-257R & 0.90 & 69.5 & $0.0^{*}$ & 0.97 & 67.5 & $0.0^{*}$ \\
\hline M. intracellulare $\mathrm{N}-260 \mathrm{~T}$ & 1.25 & 82.8 & 0.0 & 0.92 & 97.9 & 0.0 \\
\hline M. intracellulare N-260D & 1.28 & 84.3 & $0.0^{*}$ & 1.33 & 80.9 & $0.0^{*}$ \\
\hline M. intracellulare N-260R & 1.41 & 70.4 & $0.0^{*}$ & 1.68 & 63.8 & $0.0^{*}$ \\
\hline M. intracellulare N-275T & 1.12 & 83.3 & $0.0^{*}$ & 1.34 & 79.9 & $0.0^{*}$ \\
\hline M. intracellulare N-275R & 1.19 & 75.0 & $0.0^{*}$ & 1.40 & 71.4 & $0.0^{*}$ \\
\hline M. intracellulare N-279T & 1.33 & 75.7 & $0.0^{*}$ & 2.15 & 79.1 & $0.0^{*}$ \\
\hline M. intracellulare N-281D & 0.77 & 72.6 & $0.0^{*}$ & 0.98 & 67.9 & $0.0^{*}$ \\
\hline M. intracellulare Fo3193T & 0.71 & 88.3 & $0.0^{*}$ & 0.77 & 84.6 & $0.0^{*}$ \\
\hline M. intracellulare $\mathrm{K} 41014$ & 1.41 & 80.4 & 0.0 & 0.95 & 98.7 & 0.0 \\
\hline M. nonchromogenicum NC-3 & 0.43 & 96.6 & 69.1 & 0.54 & $100.0^{*}$ & 48.1 \\
\hline M. nonchromogenicum NC-11 & 0.39 & 100.0 & 43.2 & 0.18 & $100.0^{*}$ & 16.8 \\
\hline M. terrae T-7 & 0.94 & 83.0 & 68.9 & 0.91 & 78.2 & 69.8 \\
\hline M. terrae T-8 & & & & 0.27 & $100.0^{*}$ & 17.5 \\
\hline M. terrae T-13 & 0.80 & 89.4 & 37.9 & & & \\
\hline M. triviale V-4 & 0.58 & $100.0^{*}$ & $0.0^{*}$ & 0.60 & $100.0^{*}$ & $0.0^{*}$ \\
\hline M. triviale V-12 & 0.10 & 100.0 & $0.0^{*}$ & 0.09 & 100.0 & $0.0^{*}$ \\
\hline M. chelonei R-20 & 0.34 & 100.0 & 10.6 & 0.58 & 101.7 & 40.5 \\
\hline M. fortuitum F-19 & 0.58 & 76.0 & 25.1 & 1.26 & 72.7 & 66.4 \\
\hline M. smegmatis K64002 & 0.41 & 84.8 & $0.0^{*}$ & 0.56 & 88.5 & 4.6 \\
\hline
\end{tabular}

$\mathrm{ROD}=$ ratio of $\mathrm{OD}$ of heterologous over homologous reaction.

Explanation for HARD and OARH, see the text.

*Homologous or heterologous absorption did not reduce the heterologous or homologous reaction at all but it increased, instead.

M. chelonei, fortuitum, nonchromogenicum (NC-3, NC-11), and $M$. terrae, NC-3 and T-7 removed a largest amount of T-8 homologous antibody, indicating presence of a considerable amount of shared antigenic determinants on them. $M$. chelonei and fortuitum removed only $10.6 \%$ and $25.1 \%$ of the homologous reaction. T-13 antiserum was different from $T-8$ antiserum because the former showed a stronger reaction to $M$. fortuitum, kansasii, scrofulaceum and tuberculosis than the latter and T-13 homologous absorption removed less amount of antibody cross-reacting with $M$. tuberculosis. The striking differance of T-8 and T-13 antisera was a removal of homologous antibody by the heter- 
Table 2. Reactivity of Rabbits Anti-M. nonchromogenicum Sera (NC-3 and NC-11) with Other Mycobacteria

\begin{tabular}{|c|c|c|c|c|c|c|}
\hline \multirow[b]{2}{*}{ Mycobacteria } & \multicolumn{3}{|c|}{ NC-3 } & \multicolumn{3}{|c|}{ NC-11 } \\
\hline & ROD & $\begin{array}{c}\text { OARH } \\
(\%)\end{array}$ & $\begin{array}{c}\text { HARD } \\
(\%)\end{array}$ & ROD & $\underset{(\%)}{\text { OARH }}$ & $\underset{(\%)}{\mathrm{HARD}}$ \\
\hline M. tuberculosis H37Rv & 0.78 & 49.3 & $0.0^{*}$ & 0.80 & 89.4 & $0.0^{*}$ \\
\hline M. kansasii $\mathrm{K} 20001$ & 0.76 & 63.9 & $0.0^{*}$ & 0.78 & 84.6 & $0.0^{*}$ \\
\hline M. scrofulaceum K30001 & 0.42 & $100.0^{*}$ & $0.0^{*}$ & 0.75 & 93.6 & $0.0^{*}$ \\
\hline M. scrofulaceum K30003 & 0.83 & 75.6 & 13.3 & 0.94 & 81.2 & 14.7 \\
\hline M. avium $\mathrm{K} 40004$ & 1.09 & 74.0 & 18.6 & 1.07 & 95.6 & $0.0^{*}$ \\
\hline M. intracellulare N-238 & 1.05 & 75.2 & 0.0 & 0.87 & 95.5 & 0.0 \\
\hline M. intracellulare N-242D & 0.67 & 86.1 & 0.0 & 0.76 & 93.4 & $0.0^{*}$ \\
\hline M. intracellulare N-245 & 0.88 & 82.3 & 2.8 & 0.95 & 79.9 & 0.0 \\
\hline M. intracellulare N-257T & 1.15 & 72.8 & 0.0 & 0.94 & 93.6 & $0.0^{*}$ \\
\hline M. intracellulare N-257R & 0.89 & 84.7 & 6.3 & 0.86 & 86.3 & 0.0 \\
\hline M. intracellulare N-260T & 1.01 & 92.8 & 0.0 & 0.82 & 95.5 & $0.0^{*}$ \\
\hline M. intracellulare N-260D & 1.11 & 88.9 & $6.0^{*}$ & 1.05 & 89.8 & 0.0 \\
\hline M. intracellulare N-260R & 1.18 & 67.8 & 5.6 & 1.12 & 81.1 & 0.0 \\
\hline M. intracellulare N-275T & 0.89 & 87.7 & 0.0 & 0.84 & 85.3 & $0.0^{*}$ \\
\hline M. intracellulare N-275R & 1.03 & 87.5 & 0.0 & 1.01 & 84.2 & 0.0 \\
\hline M. intracellulare $\mathrm{N}-279 \mathrm{~T}$ & 1.15 & 78.0 & 5.7 & 1.03 & 87.9 & 0.0 \\
\hline M. intracellulare N-281D & 0.76 & 70.7 & 7.5 & 0.65 & 87.5 & 0.0 \\
\hline M. intracellulare Fo3193T & 0.76 & 71.5 & 0.3 & 0.69 & 85.9 & 0.0 \\
\hline M. intracellulare K41014 & 1.10 & 87.3 & 0.0 & 0.88 & 96.7 & 0.0 \\
\hline M. nonchromogenicum NC-3 & & & & 0.95 & 89.6 & 71.4 \\
\hline M. nonchromogenicum NC-6 & 0.78 & 86.0 & 86.4 & 1.07 & 84.1 & 86.5 \\
\hline M. nonchromogenicum NC-11 & 0.58 & $100.0^{*}$ & 66.4 & & & \\
\hline M. terrae T-7 & 0.71 & 87.5 & 15.8 & 0.87 & 81.5 & 14.5 \\
\hline M. terrae T-13. & 0.82 & 83.6 & 25.2 & 1.01 & 81.8 & 28.7 \\
\hline M. triviale V-4 & 0.62 & 93.3 & 0.0 & 0.54 & 88.2 & 0.0 \\
\hline M. triviale V-12 & 0.21 & 100.0 & 0.0 & 0 & 0 & 0.0 \\
\hline M. chelonei R-20 & 0.48 & 95.4 & 20.8 & 0.58 & 95.3 & $0.0^{*}$ \\
\hline M. fortuitum F-19 & 0.93 & 77.3 & 31.8 & 0.90 & 74.0 & $0.0^{*}$ \\
\hline M. smegmatis K64002 & 0.49 & 69.8 & $0.0^{*}$ & 1.43 & $100.0^{*}$ & $0.0^{*}$ \\
\hline
\end{tabular}

$\mathrm{ROD}=$ ratio of $\mathrm{OD}$ of heterologous over homologous reaction.

Explanation for HARD and OARH, see the text.

${ }^{*}$ Homologous or heterologous absorption did not reduce the heterologous or homologous reaction at all but it increased, instead.

ologous absorption with $M$. avium, kansasii, scrofulaceum, and tuberculosis. Reduction of the homologous reaction of $\mathrm{T}-13$ antiserum by $M$. chelonei and fortuitum absorption was also greater than that of T-8 antiserum. The strains of $M$. intracellulare and triviale did not reduce homologous reaction of both antisera. Rabbits immunized with both strains (T-8, T-13) of $M$. terrae produced a considerable amount of antibody cross-reacting with $M$. nonchromogenicum NC-3 though nearly all were absorbed out by homologous organisms T-8 or T-13. And NC-3 reduced $48.1 \%$ or $69.1 \%$ of the homologous reaction of $\mathrm{T}-13$ or $\mathrm{T}-8$ antiserum, indicating that NC-3 possessed a large amount of shared 
Table 3. Reactivity of Rabbits Anti-M. intracellulare Sera (N-260T, N-260D, N-260R \& K41014) with Other Mycobacteria

\begin{tabular}{|c|c|c|c|c|c|c|c|c|c|c|c|c|}
\hline \multirow[b]{2}{*}{ Mycobacteria } & \multicolumn{3}{|c|}{$\mathrm{N}-260 \mathrm{~T}$} & \multicolumn{3}{|c|}{$\mathrm{N}-260 \mathrm{D}$} & \multicolumn{3}{|c|}{$\mathrm{N}-260 \mathrm{R}$} & \multicolumn{3}{|c|}{ K41014 } \\
\hline & ROD & $\begin{array}{c}\text { OARI } \\
(\%)\end{array}$ & $\begin{array}{c}\text { HARD } \\
(\%)\end{array}$ & $\mathrm{ROD}$ & $\underset{(\%)}{\text { OARHH }}$ & $\begin{array}{l}\text { HARD } \\
(\%)\end{array}$ & ROD & $\underset{(\%)}{\text { OARHI }}$ & $\underset{(\%)}{\operatorname{HARD}}$ & ROD & $\begin{array}{c}\text { OARHH } \\
(\%)\end{array}$ & $\begin{array}{l}\text { HARD } \\
(\%)\end{array}$ \\
\hline M. tuberculosis $\mathrm{H} 37 \mathrm{Rv}$ & 0.24 & 100.0 & $0.0^{*}$ & 0.56 & 96.6 & 0.0 & 0.55 & 99.9 & 0.0 & 0.58 & 95.9 & 5.2 \\
\hline M. kansasii K20001 & 0.31 & 97.7 & $0.0^{*}$ & 0.44 & 96.9 & 0.0 & 0.75 & 98.2 & 0.0 & 0.56 & 100.0 & 3.3 \\
\hline M. scrofulaceum K30001 & 0 & 0 & 1.2 & 0.27 & $100.0^{*}$ & 7.1 & 0.38 & $100.0^{*}$ & 1.6 & 0.46 & 100.0 & 10.4 \\
\hline M. scrofulaceum K30003 & 0.34 & 100.0 & 13.0 & 0.66 & 96.0 & 18.1 & 0.65 & 98.8 & 31.5 & 0.83 & 99.1 & 24.3 \\
\hline M. avium $\mathrm{K} 40004$ & 0.33 & $100.0^{*}$ & 29.8 & 0.95 & 100.0 & 21.3 & 0.96 & 100.0 & 17.6 & 1.02 & 100.0 & 33.2 \\
\hline M. intracellulare N-238 & 0.80 & 97.4 & 24.6 & 0.84 & 94.5 & 25.0 & 0.80 & 99.5 & 59.2 & 0.85 & 98.4 & 58.9 \\
\hline M. intracellulare $\mathrm{N}$ & 0.46 & 100.0 & 13.1 & 0.58 & 100.0 & 13.1 & 0.54 & 100.0 & 32.3 & 0.60 & 100.0 & 31.4 \\
\hline M. intracellulare N-245 & 0.74 & 100.0 & 34.9 & 0.81 & 96.6 & 36.2 & 0.87 & 99.1 & 43.6 & 0.89 & 98.2 & 44.7 \\
\hline M. intracel & 0.55 & 100.0 & 10.9 & 0.66 & 100.6 & 11.2 & .55 & 100.0 & 30.5 & 0.65 & 100.0 & 29.5 \\
\hline M. intracellulare N-257R & 0.66 & 100.0 & 24.4 & 0.78 & 100.0 & 25.5 & 0.77 & 100.0 & 55.6 & 0.86 & 95.8 & 54.6 \\
\hline M. intracellulare $\mathrm{N}$ & & & & 1.11 & 94.8 & 100.0 & 1.00 & 98.3 & 98.6 & 0.96 & 100.6 & 48.9 \\
\hline M. intracellulare N-260D & 0.90 & $100.0^{*}$ & 86.2 & & & & 1.16 & 99.2 & 97.9 & 1.14 & 100.0 & 96.3 \\
\hline M. intracellulare N-260R & 1.04 & 98.0 & 92.9 & 0.98 & 93.7 & 83.8 & & & & 1.15 & 96.31 & 100.0 \\
\hline M. intracellulare N-275T & 0.56 & 100.0 & 16.9 & 0.62 & 100.0 & 15.2 & 0.65 & 97.0 & 48.0 & 0.68 & 94.8 & 47.4 \\
\hline M. intracellulare & 0.75 & 100.0 & 17.0 & 0.79 & 100.0 & 16.2 & 0.76 & 97.3 & 41.2 & 0.80 & 94.4 & 40.2 \\
\hline M. intracellulare N-279T & 0.69 & 100.0 & 32.1 & 0.73 & 100.0 & 30.7 & 0.70 & 100.0 & 45.9 & 0.91 & 92.8 & 45.5 \\
\hline M. intracellulare N-281D & 0.68 & 88.0 & 23.1 & 0.52 & 100.0 & 20.9 & 0.51 & 100.0 & 48.7 & 0.52 & 99.0 & 48.4 \\
\hline M. intracellulare Fo3193T & 0.57 & 100.0 & 41.2 & 0.66 & 100.0 & 40.8 & 0.58 & 100.0 & 47.7 & 0.57 & 100.0 & 47.0 \\
\hline M. intracellulare K41014 & 0.83 & 100.0 & 57.9 & 0.90 & 96.0 & 82.1 & 0.91 & 100.0 & 99.8 & & & \\
\hline M. nonchromogenicum NC-3 & 0 & 0 & 8.3 & 0.09 & $100.0^{*}$ & 4.5 & 0.01 & 100.0 & 10.2 & 0.34 & 100.0 & 2.6 \\
\hline M. nonchromogenicum NC-11 & 0 & 0 & 0.4 & 0 & 0 & 4.8 & 0 & 0 & 0.0 & 0.17 & 100.0 & 5.7 \\
\hline M. terrae T-7 & 0.08 & $100.0^{*}$ & 0.0 & 0.11 & $100.0^{*}$ & 0.0 & 0.10 & $100.0^{*}$ & $0.0^{*}$ & 0.37 & 100.0 & 0.0 \\
\hline M. terrae $\mathrm{T}-13$ & 0.16 & $100.0^{*}$ & 18.2 & 0.11 & $100.0^{*}$ & 5.8 & 0.27 & 92.7 & 17.7 & 0.46 & 96.4 & 13.7 \\
\hline M. triviale V-4 & 0.02 & 100.0 & 2.4 & 0.09 & 100.0 & 0.0 & 0.17 & $100.0^{*}$ & $0.0^{*}$ & 0.18 & $100.0^{*}$ & $0.0^{*}$ \\
\hline M. triviale $\mathrm{V}-12$ & 0 & 0 & 5.4 & 0 & 0 & 6.2 & 0 & 0 & $0.0^{*}$ & 0 & 0 & $0.0^{*}$ \\
\hline M. chelonei R-20 & 0 & 0 & 11.9 & 0.11 & $100.0^{*}$ & 8.3 & 0.01 & 0 & 22.2 & 0.16 & $100.0^{*}$ & 9.6 \\
\hline M. fortuitum F-19 & 0.17 & $100.0^{*}$ & $0.0^{*}$ & 0.07 & $100.0^{*}$ & 0.0 & 0.20 & $100.0^{*}$ & 4.9 & 0.51 & 100.0 & 6.0 \\
\hline M. smegmatis $\mathrm{K} 64002$ & 0.09 & $100.0^{*}$ & $0.0^{*}$ & 0.15 & 100.0 & 0.0 & 0.17 & $100.0^{*}$ & 0.0 & 0.40 & 100.0 & 4.2 \\
\hline
\end{tabular}

$\mathrm{ROD}=$ ratio of $\mathrm{OD}$ of heterologous over homologous reaction.

Explanation for HARD and OARH, see the text.

*Homologous or heterologous absorption did not reduce the heterologous or homologous reaction at all but it increased, instead.

antigenic determinants. Unlike $\mathrm{T}-8, \mathrm{~T}-13$ did not raise much of antibody cross-reacting with $\mathrm{NC}-11$ in rabbits and $\mathrm{NC}-11$ reduced only $16.8 \%$ of homologous reaction.

There were of course a considerable amount of shared antigens between the strains of $M$. terrae. T-8 antiserum reacted strongly with T-7 (ROD, 0.94) and
T-13 (ROD, 0.80 ) which of $83.0 \%$ and $89.4 \%$ were removed by the homologous (T-8) absorption. T-7 reduced $68.9 \%$ of the homologous reaction of $\mathrm{T}-8$ antiserum, while $\mathrm{T}-13$ reduced merely $37.9 \%$, indicating that $\mathrm{T}-7$ cell surface possessed larger amount of shared antigens than T-13. T-13 antiserum also showed a strong reaction with $T-7$ which of 
$78.2 \%$ were removed by the homologous absorption and T-7 absorption of T-13 antiserum reduced $69.8 \%$ of homologous reaction. In contrast with T-8, T-13 produced a small amount of antibody reacting with $\mathrm{T}-8$ in rabbits and T-8 was able to absorb out merely $17.5 \%$ of homologous reaction. This finding suggeses that antigenic relationship of $T-7$ is equally close with T- 8 and T- 13 and T- 8 cell surface possess a measurable amount of antigens shared with $\mathrm{T}-13$ but not much of shared antigen on $\mathrm{T}-13$ cell surface.

Rabbits antisera raised with $M$. nonchromogenicum NC-3 and NC-11 contained a large amount of cross-reacting antibody against other mycobacteria except $M$. triviale. NC-3 antiserum unlike NC-11 serum showed a relatively weak reaction to $M$. chelonei, scrofulaceum(K30001) and smeg. matis. Nearly all of these cross-reacting antibody ( $>$ $90 \%$ ) to K30001, R-20, V-4 and V-12 were removed by the homologous absorption. More than $80 \%$ of the heterologous reaction of NC-3 antiserum with $M$. intracellulare strains (N-242D, N-245, N257R, N260T, N-260D, N-275T, N-275R, K41014), and $M$. terrae were removed by the homologous reaction and $70 \sim 79 \%$ removal with $M$. avium, fortuitum, the rest of intracellulare strains, scrofulaceum(K30003), and smegmatis. Homologous absorption, however, removed $49.3 \%$ and $63.9 \%$ of antibody crossreacting with $M$. tuberculosis and kansasii respectively. Homologous reaction was not reduced much by the heterologous absorption except for $M$. avium, chelonei, fortuitum, scrofulaceum(K30003), and terrae. $M$. chelonei and fortuitum reduced $20.8 \%$ and $31.8 \%$ of homologous reaction. $M$. terrae $\mathrm{T}-7$ and T-13 reduced $15.8 \%$ and $25.2 \%$ respectively, $M$. avium, $18.6 \%$ and $M$. scrofulaceum(K30003), 13.3\%. More than $80 \%$ of NC-11 antiserum reaction with other mycobacteria except for $M$. triviale V-12 and fortuitum were removable by the homologous absorption. NC-11 antiserum did not contain a measurable amount of antibody reacting with $M$. triviale V-12. Homologous absorption of NC-11 antiserum reduced
Table 4. Reactivity of Rabbits Anti-M. avium Sera (K40004) with Other Mycobacteria

\begin{tabular}{|c|c|c|c|}
\hline \multirow[b]{2}{*}{ Mycobacteria } & \multicolumn{3}{|c|}{ K40004 } \\
\hline & ROD & $\underset{(\%)}{\text { OARH }}$ & $\underset{(\%)}{\text { HARD }}$ \\
\hline M. tuberculosis $\mathrm{H} 37 \mathrm{Rv}$ & 0.48 & 87.5 & 9.2 \\
\hline M. kansasii $\mathrm{K} 20001$ & 0.29 & 100.0 & 13.6 \\
\hline M. scrofulaceum K30001 & 0.14 & 100.0 & 37.5 \\
\hline M. scrofulaceum K30003 & 0.46 & 78.2 & 69.3 \\
\hline M. intracellulare N-238 & 0.36 & 99.3 & 88.8 \\
\hline M. intracellulare N-242D & 0.14 & $100.0^{*}$ & 63.7 \\
\hline M. intracellulare N-245 & 0.38 & 89.5 & 70.6 \\
\hline M. intracellulare N-257T & 0.19 & $100.0^{*}$ & 63.0 \\
\hline M. intracellulare $\mathrm{N}-257 \mathrm{R}$ & 0.51 & 97.8 & 87.5 \\
\hline M. intracellulare $\mathrm{N}-260 \mathrm{~T}$ & 0.49 & $100.0^{*}$ & 61.8 \\
\hline M. intracellulare N-260D & 0.71 & 100.0 & 75.8 \\
\hline M. intracellulare $\mathrm{N}-260 \mathrm{R}$ & 0.44 & 100.0 & 50.6 \\
\hline M. intracellulare N-275T & 0.30 & 89.6 & 63.4 \\
\hline M. intracellulare N-275R & 0.38 & 100.0 & 58.8 \\
\hline M. intracellulare N-279T & 0.41 & 100.0 & 67.9 \\
\hline M. intracellulare N-281D & 0.25 & 100.0 & 66.2 \\
\hline M. intracellulare Fo3193T & 0.39 & 81.4 & 84.4 \\
\hline M. intracellulare K41014 & 0.72 & 95.1 & 75.0 \\
\hline M. nonchromogenicum NC-3 & 0.06 & 53.1 & 55.1 \\
\hline M. nonchromogenicum NC-11 & 0.05 & 93.2 & 0.0 \\
\hline M. terrae T-7 & 0.02 & 0 & 0.0 \\
\hline M. terrae T-13 & 0.28 & 89.7 & 39.7 \\
\hline M. triviale V-4 & 0.04 & 0 & 1.8 \\
\hline M. triviale V-12 & 0.11 & $100.0^{*}$ & 43.9 \\
\hline M. chelomei $\mathrm{R}-20$ & 0.04 & 0 & 60.8 \\
\hline M. fortuitum F-19 & 0.14 & 100.0 & 18.6 \\
\hline M. smegmatis $\mathrm{K} 64002$ & 0.18 & $100.0^{*}$ & 6.9 \\
\hline
\end{tabular}

$\mathrm{ROD}=$ ratio of $\mathrm{OD}$ of heterologous over homologous reaction.

Explanation for HARD and OARH, see the text.

*Homologous or heterologous absorption did not reduce the heterologous or homologous reaction at all but it increased, instead.

$74.0 \%$ of heterologous reaction with $M$. fortuitum. Heterologous absorption of NC-11 antiserum with the various mycobacteria except $M$. scrofulaceum K30003 and terrae did not reduced homologous reaction, on the contrary, it increased in many occasions, 
suggesting that some homologous antibody might have cross-linked heterologous antigens bearing shared antigenic dorminants, on which additional antibodies were bound, to the coated homologous antigens. As it was in NC-3 antiserum, $M$. scrofulaceum $\mathrm{K} 30003$, terrae $\mathrm{T}-7$ and $\mathrm{T}-13$ reduced $14.7 \%, 14.5 \%$ and $28.7 \%$ of the homologous reaction respectively.

Although NC-3 antiserum showed a little less strong reaction to NC-11 and heterologous absorption with NC-11 reduced homologous reaction less when compared with those of NC-6, close antigenic relationship was observed between the strains of $M$. nonchromogenicum because their antiserum crossreacted strongly and a great reduction of homologous or heterologous reaction was occurred by the heterologous or homologous absorption.

Rabbits immunized with $M$. intracellulare N-260T did not produce a measurable antibody reacting with M. chelonei, nonchromogenicum NC-3 \& NC-11, scrofulaceum K30001, smegmatis, terrae T-7, and triviale V-4 \& V-11 and produced very small amount of cross-reacting antibody to $M$. fortuitum, terrae $\mathrm{T}-13$, and tuberculosis, all of which were easily removable by the homologous absorption. N-260T antiserum also reacted weakly with $M$. scrofulaceum K30003 and avium K40004 and the homologous absorption removed all of these antibody. However K30003 or K40004 absorption reduced merely 13.0\% or $29.8 \%$ of the homologous reaction. $\mathrm{N}-260 \mathrm{D}$ and $\mathrm{N}-260 \mathrm{R}$ antisera also did not react at all or weakly reacted with $M$. chelonei, fortuitum, nonchromogenicum, smegmatis, terrae and triviale. K41014 antiserum did not react or weakly reacted with $M$. chelonei, nonchromogenicum $\mathrm{NC}-11$, and triviale. All the antisera except N-260T antiserum had a considerable amount of antibody to $M$. tuberculosis H37Rv which of more than 95\% were absorbed by the homologous absorption, whereas H37Rv absorption did not reduce the homologous reaction. Relatively small amount of antibody reacting with
M. kansasii was present homologous reaction. Relatively small amount of antibody reacting with M. kansasii was present in N-260T and N-260D antisera and a considerable amount in N-260R and K41014 antisera, all of which could be removed by the homologous absorption. $M$. kansasii absorption did not reduce the homologous reaction of all of $M$. intracellulare antisera. M. scrofulaceum K30001 antibody was present in a relatively small amount in $\mathrm{N}-260 \mathrm{D}$ and $\mathrm{N}-260 \mathrm{R}$ antisera and a considerable amount in K41014 antiserum and the homologous absorption removed all these cross-reacting antibody but K30001 absorption did not reduce the homologous reaction except K41014 serum whose homologous reaction was reduced $10.4 \%$ by this strain (K30001). The other strain (K30003) of $M$. scrofulaceum seemed to show a closer antigenic relationship with $M$. intracellulare because all the $M$. intracellulare antisera except $\mathrm{N}-260 \mathrm{~T}$ antiserum showed a 0.65 or higher RODs to this species and $\mathrm{K} 30003$ absorption reduced $18.1 \%, 24.3 \%$ or $31.5 \%$ of the homologous reaction of $\mathrm{N}-260 \mathrm{D}, \mathrm{K} 41014$ or $\mathrm{N}-260 \mathrm{R}$ antiserum respectively. Except N-260T antiserum, all the other antisera contained a large amount of antibody to $M$. avium K40004 and all these antibody were removed by the homologous absorption. M. avium absorption reduced $17.6 \%, 21$. $3 \%$ or $33.2 \%$ of the homologous reaction of $\mathrm{N}-260 \mathrm{R}$, $\mathrm{N} 260 \mathrm{D}$ or K41014 antiserum respectively. A close antigenic relationship was of course observed between the strains of $M$. intracellulare, $M$. avium and scofulaceum $\mathrm{K} 30003$ also showed a close antigenic relationship with the strains of $M$. intracellulare used for antiserum production. N-260T antiserum showed a relatively weak reaction against N-242D, N-257T, N-275T, and Fo3193T and a moderately strong reaction against N-245, N-257R, N275R, $\mathrm{N} 279 \mathrm{~T}$, and N-281D. Relatively strong reactions (RODs, >0.80) were observed with N-238, N260D, $\mathrm{N}-260 \mathrm{R}$ and K41014. Homologous absorption removed $100 \%$ or nearly so of these cross-reacting 
antibody. Antigenic relationship between N-260T, $\mathrm{N} 260 \mathrm{D}$, and $\mathrm{N}-260 \mathrm{R}$ was so close that their homologous or heterologous absorption rendered almost complete reduction of homologous or heterologous reaction. A close antigenic relationship was also evident between N-260T, N260D, and K41014. However antigenic relationship between $\mathrm{N}-260 \mathrm{~T}$ and K41014 was somewhat less close because their heterologous absorption reduced merely $48.9 \%$ or $57.9 \%$ of the homologous reaction even if their antisera cross-reacted strongly to each other and homologous absorption removed all of these crossreacting antibody. In other words, shared antigens between N-260T and K41014 were present on their cell surface in smaller amount than those between the other strains. The heterologous absorption of $\mathrm{N}-260 \mathrm{~T}$ antiserum with N-257T, N242D, N-275T, and $\mathrm{N}-275 \mathrm{R}$, reduced less than $20 \%$ of the homologous reaction and with the other strains, $23 \sim 41 \%$. Serological reactivity of $\mathrm{N}-260 \mathrm{D}$ antiserum with the other strains, N-260T, N-260R, and K41014, was very similar with N-260T antiserum. N-260D antiserum reacted weakly with N-242D, N-257T, N-281D, Fo3193T, and N-275T, that absorbed out approximately $30 \sim 49 \%$ of the homologous reaction. $\mathrm{N}-238$ and $\mathrm{N}-275 \mathrm{R}$ showed somewhat close antigenic relationship with N-260R next to N-260T, N-260D, and K41014. K41014 antiserum showed a relatively weak reaction with N-281D, Fo3193T, N-242D, N-257T, and N-275T, that absorbed out approximately 29 $\sim 49 \%$ of the homologous reaction. This strain also seemed to have somewhat close antigenic relationship with $\mathrm{N}-238$ and $\mathrm{N}-275 \mathrm{R}$ next to the intimate strains N-260T, N260D, and N-260R.

M. avium $\mathrm{K} 40004$ antiserum unlike other antisera reacted with the other mycobacteria. Of the strains of taxonomically and antigenically close species $M$. intracellulare and scrofulaceum, N-260D and K41014 showed most strong reaction (RODs, 0.71 and 0.72 ) with $M$. avium antiserum and RODs of $M$. intracellulare N-238, N-245, N275T, N275R, N281D, and
Fo3193T were 0.20 0.39. M. avium antiserum reacted very weakly with all the other mycobacteria. Most of these cross-reacting antibody were removed by the homologous absorption. RODs of $M$. tuberculosis $\mathrm{H} 37 \mathrm{Rv}$ and kansasii $\mathrm{K} 20001$ reaction over $M$. avium homologous reaction were 0.48 and 0.29 respectively and these species reduced $9.2 \%$ and $13.6 \%$ of the homologous reaction. All the strains of $M$. intracellulare reduced more than $50.0 \%$ of $M$. avium homologous reaction indicating an abundance of shared antigens on them. $M$. scrofulaceum also considerably reduced homologous reaction and a greater reduction was obtained with K30003 than with K30001. M. avium antiserum did not react with $M$. terrae T-7 but weakly with T-13 that absorbed out $39.7 \%$ of the homologous reaction. Very weak or no reaction was also observed with $M$. chelonei, fortuitum, nonchromogenicum NC-3 \& NC-11, smegmatis, and triviale V-4 \& V-12.

\section{DISCUSSION}

It has been long understood there are considerable amount of the antigenic cellular constituents or metabolites shared by a wide range of mycobacterial species, which might be closely related to their phylogeny. Though the phenetic configuration of antigenic structure should be useful to delineate the phylogenetic relationship between different mycobecterial taxons, most of the recent immunological technology have not been proved to make it possible mainly due to the variation in antigenic expression of individual strains depending on the cultural conditions and to the heterogeneity in immunogenecity of individual antigens and in immune response of individual hosts. Nevertheless several immunological procedures have been successfully used for the classification and identification of certain mycobacterial species, subspecies or serobars. Shaeffer's seroagglutination tests opened a way of serotaxonomic scheme of mycobacteria and 
it has been found very useful for the taxonomy of $M$. avium-intracellulare-scrofulaceum(MAIS) complex and some other mycobacteria ${ }^{9}$. This procedure, however, is not applicable to the mycobacterial species or strains whose colony is rough or dry. Immunodiffusion and immunoelectrophoresis have been also found useful to elucidate the antigenic relationships of mycobacteria although they have some drawbacks too because the antigens and antisera used in these procedures have not been standardized so that each laboratory uses its own reference reagents ${ }^{10}$. Rabbits immunized with $M$. terrae $\mathrm{T}-8$ or $\mathrm{T}-13$ produced a large amount of antibody cross-reacting with $M$. avium and intracellulare strains and the homologous absorption removed most of these cross-reacting antibody to the majority of strains but less to certain strains such as N-257R, $\mathrm{N}-260 \mathrm{R}$, and N-281D that may possess shared antigens more than $M$. terrae, $M$. intracellulare strains bear a considerable amount of antigens shared with $M$. terrae that does not possess much as they did not reduced homologous reaction. $M$. avium did not reduce homologous reaction of $\mathrm{T}-8$ antiserum at all but $35.6 \%$ of $\mathrm{T}-13$ antiserum indicating the presence of a considerable amount of shared antigens on $\mathrm{T}-13$ cell surface. It was obvious that amounts of shared antigens on the different strains of $M$. intracellulare varied as the removal of cross-reacting antibody by the homologous absorption was not same between the strains.

In contrast with $M$. terrae antisera, $M$. avium and intracellulare antisera except $\mathrm{K} 41014$ showed a very weak or no reaction to $M$. terrae and their homologous reaction was not reduced much by $M$. terrae absorption with an exception of $M$. avium antiserum whose homologous reaction was reduced $39.1 \%$ by $M$. terrae $\mathrm{T}-13$ absorption.

$M$. terrae antisera reacted weakly with $M$. nonchromogenicum, however the latter species absorbed out a considerable amount of homologous reaction probably due to comparative abundance of shared antigens on both species. Antigenic sharing between T-13 and NC-11 was apparently less remarkable than between T-13 and NC-3. M. nonchromogenicum antisera showed a strong reaction indicating a close antigenic relationship. $M$. terrae seemed not to have a close antigenic relationship with $M$. triviale because antiserum of the former species did not or weakly react with the strains of the latter species that did not reduce their homologous reaction. $M$. fortuitum showed a considerably close antigenic relationship with $M$. terrae especially T-13. T-13 antiserum recognized $M$. fortuitum even closer than T-8 with which it reacted weakly and it's homologous reaction was reduced much less by T-8 absorption than by F-19.

$\mathrm{T}-8$ and $\mathrm{T}-13$ were found to be antigenically close with $\mathrm{T}-7$ but less close to each other as though T-13 possessed some more shared antigens than $\mathrm{T}-8$ because reaction to $T-13$ was stronger and reduction of $\mathrm{T}-8$ homologous reaction was larger.

Reaction with $M$. kansasii, scrofulaceum, and tuberculosis was strikingly different between $T-8$ and $\mathrm{T}-13$ antisera of which the former serum reacted weakly with them and it's homologous reaction was not reduced by the heterologous absorption with them, whereas the latter serum showed a strong reaction with them and their absorption reduced homologous reaction considerably. $M$. kansasii or tuberculosis cross-reacting antibody in $M$. terrae antiserum were removed less by the homologous absorption when compared with others, suggesting that shared antigenic determinants distributed in a considerable amount on $M$. kansasii or tuberculosis, on the contrary they are very rare on $T-8$ and relatively small on T-13.

$M$. scrofulaceum $\mathrm{K} 30003$ seemed to be antigenically closer to $M$. terrae than K30001.

$M$. nonchromogenicum antisera cross-reacted strongly with the other mycobacteria except few species. Homologous absorption removed most of those cross-reacting antibody with and exception 
that reaction of NC-3 antiserum to $M$. tuberculosis was reduced merely $49.3 \%$ by the homologous absorption. Close antigenic relationship was obvious only between them next to $M$. terrae and scrofulaceum K30003. M. avium, chelonei, and fortuitum reduced homologous reaction of NC-3 antiserum considerably, indicating a good amount of antigenic sharing. The findings that NC-3 antiserum showed a weaker reaction with NC-11 than with NC-6 and the homologous reaction was reduced more by $\mathrm{NC}-6$ absorption than by $\mathrm{NC}-11$ indicated that $\mathrm{NC}-3$ was antigenically closer with NC-6 than with NC-11. Analysis of NC-11 antiserum reaction also confirmed such relationship.

M.terrae antisera reacted weakly with $M$. nonchromogenicum but there were considerable amount of shared antigens on both organisms. It was interesting to note that $M$. nonchromogenicum antisera reacted strongly with $M$. avium and intracellulare while antiserum of the latter species poorly or did not react with $M$. nonchromogenicum.

$M$. intracellulare antiserum assay revealed that strains of this species seemed to have no or very little antigenic sharing with $M$. chelonei, fortuitum, nonchromogenicum, scrofulaceum K30001, smegmatis, and triviale. $M$. chelonei and terrae T-13 possessed certain amount of antigens shared with $M$. intracellulare and vice versa. A close antigenic relationship of the strains of $M$. intracellulare was found to be with $M$. avium and scrofulaceum K30003. And it was not clearly understood why $M$. scrofulaceum K30001 was antigenically estranged from $M$. intracellulare, $M$. kansasii and tuberculosis reacted weakly with $M$. intracellulare antisera except $\mathrm{N}-260 \mathrm{R}$ antiserum reaction to kansasii and did not reduce the homologous reaction of intracellulare antisera, suggesting a paucity of antigenic sharing. Though there were considerable strain variation in heterologous reaction between strains of $M$. intracellulare, a large antigenic sharing was evidently intraspecific and most close antigenic relationship was found between
K41014, N-260D, N-260R, and N-260T, of which they showed an equal closeness to each other except between $\mathrm{N}-260 \mathrm{~T}$ and $\mathrm{K} 41014$. Intraspecific heterologous reaction was removed easily by the homologous absorption, whereas reduction of the homologous reaction by heterologous absorption was different depending on the extent of antigenic sharing. Reduction of N-260D antiserum homolgous reaction by intraspecific heterologous absorption was found in order with $\mathrm{N}-260 \mathrm{~T}>\mathrm{N}-260 \mathrm{R}=$ K41014 $>$ Fo3193T $>\mathrm{N}-245>\mathrm{N}-279 \mathrm{~T}$, reduction of $\mathrm{N}-260 \mathrm{R}$ antiserum reaction with $\mathrm{K} 41014=\mathrm{N}-260 \mathrm{~T}=$ $260 \mathrm{D}>\mathrm{N}-238>\mathrm{N}-257 \mathrm{R}>\mathrm{N}-281 \mathrm{D}=\mathrm{N}-275 \mathrm{~T}=$ Fo3193 $>$ N-279T $>$ N-245 $>$ N-275R, reduction of $\mathrm{N}$ $260 \mathrm{~T}$ antiserum reaction with $\mathrm{N}-260 \mathrm{R}>\mathrm{N}-260 \mathrm{D}>$ $\mathrm{K} 41014>$ Fo3193T $>\mathrm{N}-245>\mathrm{N}-279 \mathrm{~T}$, and reduction of K41014 antiserum with $\mathrm{N}-260 \mathrm{R}>\mathrm{N}-260 \mathrm{D}>\mathrm{N}$ $238>\mathrm{N}-257>\mathrm{N}-260 \mathrm{~T}=\mathrm{N}-281 \mathrm{D}=\mathrm{N}-275 \mathrm{~T}>\mathrm{N}-279 \mathrm{~T}=$ $\mathrm{N}-245>\mathrm{N}-275 \mathrm{R}$.

$M$. avium antiserum did not contain much of interspecific cross-reacting antibody, for example it did not react at all with $M$. chelonei, nonchromogenicum NC-3 \& NC-11, terrae T-7, and triviale V-4, and very weakly reacted with fortuitum F-19, intracellulare N-242D \& N-257T, scrofulaceum K30001, smegmatis and triviale V-12. Relatively strong reaction was found with $M$. intracellulare N-260D and K41014. Most of cross-reacting antibody were removed by the homologous absorption suggesting abundance of shared antigens on $M$. avium cell surface. Abundance of shared antigens on $M$. avium cell surfaces were confirmed again by observing a great reduction of homologous reaction by the heterologous absorption with menbers of MAIS complex. Though $M$. intracellulare $\mathrm{N}-242 \mathrm{D}, \mathrm{N} 257 \mathrm{~T}$ and $\mathrm{N}-281 \mathrm{D}$ reacted very weakly with $M$. avium antiserum, they reduced more than $63 \%$ of the homologous reaction, suggesting that a large amount of shared antigens were distributed on $M$. avium cell surface while poor on those three strains. Whether the same explanation could be applied for a considerable reduction of 
homologous reaction by $M$. chelonei, nonchromogenicum NC-3, terrae $\mathrm{T}-13$, and triviale V-12 is not known.

\section{SUMMARY}

Cell surface antigenic relationships between pathogenic mycobacteria have been investigated by the enzyme-linked immunosorbent assay using phenolkilled cells and their rabbits antisera.

Homologous and heterologous reactions of Mycobacterium avium-intracellulare antisera before and after homologous and heterologous absorption revealed a close antigenic relationship between strains of the same species and between species if they were members of $M$. avium(MA)intracellulare(MI)-scrofulaceum(MG) complex. MAI sera showed a considerable reaction with $M$. kansasii(MK) and tuberculosis(MTB), but not with the other species. MA(K40004) antiserum reacted with other mycobacteria except few strains of MI and $50 \sim 89 \%$ of homologous reaction was reduced by heterologous absorption with cells of MI or MS. Intraspecific reaction of MI antisera was naturally stronger than interspecific reaction and different in extent due to a magnitude of antigenic sharing. Antigenic relationships between N-260D, N-260R, $\mathrm{N}-260 \mathrm{~T}$, and K41014 was somewhat closer than that with N-242D, N-257T, N-281D, and N-275T.

$M$. nonchromogenicum (MNC) antisera showed a strong interspecific reaction with exception of $M$. chelonei(MC) and triviale(MTV) to which they reacted weakly or none. Antigenic sharing with $M$. terrae(MTR) and $\mathrm{MG}(\mathrm{K} 30003)$ was next to intraspecific sharing. NC-3 shared antigens considerably with MA, MC, and $M$. fortuitum $(\mathrm{MF})$ while NC-11 did not.

MTR antisera showed a strong cross-reaction with MI but their homologous reaction was not reduced by MI absorption indicating a paucity of shared antigen of MTR surface. Intraspecific antigenic sharing of course was large with on exception between T-8 and T-13. A considerable amount of antigenic sharing was also found with $\mathrm{MNC}, \mathrm{MC}$ and MF. Unlike T-8 serum, T-13 antiserum strongly cross-reacted with MA, MG, MK, and MTB.

In general, antigenic relationships of mycobacteria, that have been elucidated in this study, well conformed to taxons delineated by the various biological and biochemical means.

\section{REFERENCES}

1) Tsukamura M: Some considerations regarding the classification and identification of mycobaceria. Rev Infect Dis 3:829-840, 1981

2) Wayne LG: Mycobacterial speciation. In. The mycobacteria-a sourcebook. 1984 pp 25-65, Ed, Kubica GP and Wayne, Marcel Dekker Inc, New York and Basel

3) Baess I: Deoxyribonucleic acid relatedness among species of slowly growing mycobacteia. Acta Pathol Microbiol Scand Sect B 87:221-226, 1979

4) Baess I: Deoxyribonucleic acid relatedness among species of rapidly growing mycobacteia. Acta Pathol Microbiol Scand Sect B 90:371-375, 1982

5) Magnusson M: Immunological classification using sensitins. In. The mycobacteria-a sourcebook. 1984 pp 83-104. Ed, Kubica GP and Wayne, Marcel Dekker Inc, New York and Basel.

6) Ridell N, Portaels F: Immunodiffusion analysis of environmental mycobacteria isolated in Zaire. $\mathrm{Zbl}$ Bakt Hyg A260:286-292, 1985

7) Stanford JL: Immunologically important constituents of mycobacteria: antigens. In. The biology of the mycobacteria. Vol. 2, pp 85-128. Ed, by Ratledge $\mathrm{C}$ and Stanford J, Academic press Inc., New York, 1983

8) Brennan PJ: Structure of mycobacteria: recent developments in defining cell wall carbohydrates and proteins. Rev Infect Dis 11(Suppl 2):S420-S430, 1989

9) Wolinsky E, Shaefer WB: Proposed numbering scheme for mycobacterial serotypes by agglutination. Intern J Syst Bacteriol 23:182-183, 1973

10) Lind $A$ and Ridell M: Mycobacterial species; immunological classification. Immunodiffusion and immunoelectrophoresis. In. The mycobacteria-a sourcebook. 1984 pp 67-82, Ed, Kubica GP and Wayne, Marcel Dekker Inc. New York and Base1 